GOLD Reports. Available at: https://goldcopd.org/gold-reports/ (Accessed: December 11, 2018).

2. Barnes P.J. Cellular and molecular mechanisms of chronic obstructive pulmonary disease. Clin. Chest Med. 2014; 35 (1): 71-86. DOI: $10.1016 /$ j.ccm.2013.10.004.

3. Cataldo D., Derom E., Liistro G. et al. Overuse of inhaled corticosteroids in COPD: five questions for withdrawal in daily practice. Int. J. Chron. Obstruct. Pulmon. Dis. 2018; 13: 2089-2099. DOI: $10.2147 /$ COPD.S164259.

4. Gershon A.S., Campitelli M.A., Croxford R. et al. Combination long-acting $\beta$-agonists and inhaled corticosteroids compared with long-acting $\beta$-agonists alone in older adults with chronic obstructive pulmonary disease. JAMA. 2014; 312 (11): 1114-1121. DOI: 10.1001/jama.2014.11432.

DOI https://doi.org/10.30525/978-9934-588-81-5-1.23

\title{
ОСОБЛИВОСТІ КЛІНІЧНОЇ КАРТИНИ ХВОРИХ ІЗ ПРОСТАТИЧНОЮ ІНТРАЕПІТЕЛІАЛЬНОЮ НЕОПЛАЗІЕЮ
}

\author{
Зайцев В. I. \\ кандидат медичних наук, професор, \\ професор кафедри урології та нейрохірургії \\ ВДНЗ «Буковинський державний медичний університет» \\ Ілюк I. I. \\ кандидат медичних наук, доиент, \\ доиент кафедри урології та нейрохірургії \\ ВДНЗ «Буковинський державний медичний університет» \\ Марчук О. А. \\ лікар-інтерн уролог, \\ кафедра урології та нейрохірургії \\ ВДНЗ «Буковинський державний медичний університет» \\ м. Чернівиі, Україна
}

Актуальність. На сьогоднішній день, виявлення раку простати на ранній стадії залишається актуальною проблемою в усьому світі. На жаль основні методи діагностики РП, такі як: пальцеве ректальне 
дослідження простати, трансректальне УЗД залози, визначення рівня ПСА в сироватці крові, не завжди дозволяють виявити пухлинний процес на ранніх стадіях. Діагностування раку простати на початковій стадії, має важливе значення, оскільки від цього буде залежати подальша тактика лікування.

Простатична інтраепітеліальна неоплазія (ПІН) або епітеліальна дисплазія - являється передраковим станом простати. За даними літератури, частота виявлення ПІН, при ініціальній біопсії складає від $0,4 \%$ до $25 \%$.

Мета роботи: визначити частоту виявлення ПІН після проведення ТУР постати та ознаки, які можуть сприяють розвитку або свідчити про наявність ПІН, а також клінічні ознаки хворих з ПІН та раку простати.

Матеріал та методи дослідження: було проаналізовано 184 історій хвороб пацієнтів із доброякісною гіперплазією простати (ДГП) та раком простати (РП), яким проводили трансуретральну резекцію простати (ТУР). Зі 106 хворих з ДГП у 100 хворих було гістологічно підтверджено ДГП, а у 6 хворих - простатична інтраепітеліальна неоплазієя (ПІН).

Окремо було проаналізувано 78 історій хвороб хворим, яким проводили ТУР простати і був діагностований інцидентальний рак простати.

Досліджувані ознаки: вік, індекс маси тіла, наявність епіцистостоми, гематурія, гостра затримка сечі, хронічна затримка сечі, хронічний цистит, хронічний простатит, атонія сечового міхура, наявність цукрового діабету, об'єм простати, наявність кальцинатів у простаті, попереднє застосування альфа - адреноблокаторів, попередні ТУР простати.

Результати досліджень: Середній вік у хворих з ДГПЗ - $70 \pm 11$ років, у хворих з ПІН $=67 \pm 9$ років, у хворих 3 раком простати $74 \pm 12$ років, значущої різниці немає. При дослідженні індекса маси тіла у всіх групах хворих значущої різниці немає. Наявність епіцистостоми у хворих з ДГПЗ $=28 \%$, у хворих з раком простати $=16,7 \%$, у жодного хворого з ПІН епіцистостомічного дренажу не спостерігалося - $0 \%$. Гематурія була наявна у $16 \%$ хворих з ДГПЗ, 5, $1 \%$ з РП, та в жодного хворого з ПІН. Гостра затримка сечі наявна у 47\% хворих 3 ДГПЗ, 50\% з РП та $83 \%$ у хворих з ПІН. Хронічний цистит виявлений у 48\% з ДГПЗ, 66,6 \% з ПІН та 88,5 з РП. Атонія сечового міхура - у 6\% з ДГПЗ і жодного випадку з ПІН та РП. Середній об'єм простати = $51 \pm 21 \mathrm{~cm}^{3}$ хворих з ДГПЗ, $64 \pm 23 \mathrm{~cm}^{3}$ з ПІН та $52 \pm 18 \mathrm{~cm}^{3}$ з раком проста- 
ти. Цукровий діабет спостерігався у 3\% хворих з ДГПЗ, 33,3\% з ПІН та 2,5 \% з РП. Кальцинати в простаті були наявні у 3\% хворих з ДГПЗ, та в жодного хворого з ПІН та РП. Хронічна затримка сечі наявна у 33\% хворих з ДГПЗ, 16\% зПІН та 50\% з РП. Неефективність попередньго застосування альфа 1 адреноблокаторів спостерігалася у 17\% хворих з ДГПЗ, 33,3\% з ПІН та 19,2\% з РП. Хронічний простатит наявний у $56 \%$ хворих з ДГПЗ, 83\% з ПІН та $51 \%$ з раком простати. У жодного хворого попередніх випадків ТУР не спостерігалося.

Проаналізувавши результати досліджень, ми встановили, що частота виявлення простатичної інтраепітеліальної неоплазії при трансуретральній резекції простати склала 4,4\%. Такі показники як вік, IMT, атонія сечового міхура, кальцинати в простаті, гематурія не мають достовірної різниці, що могла б свідчити про наявність у хворого ПІН. Середній об'єм простати був дещо більшим у хворих з ПІН. Хоча достовірної різниці з іншими групами встановлено не було, ми припускаємо, що хворі які мають об'єм простати $60 \mathrm{~cm}^{3}$ та більше, мають вищий ризик існування ПІН. Неефективність попередньго застосування альфа 1 адреноблокаторів спостерігалася частіше у групі з ПІН, дещо рідше при РП, найрідше - при ДГП. Хоча достовірна різниця відсутня, існує тенденція до того, що неефективність попередньго застосування альфа-1 адреноблокаторів може бути прогностичною ознакою існування ПІН та раку простати, оскільки ракові клітини можуть на фізичному рівні впливати на чутливість альфа-1 адренорецепторів. Цукровий діабет спостерігався у 3\% хворих з ДГПЗ, 33,3\% 3 ПІН та 2,5 \% з РП. Хронічний простатит найчастіше діагностувався у хворих з ПІН. Добре відомо, що запальні захворювання простати $\epsilon$ причиною виникнення ПІН. Тому хворі, які мають хронічні запальні процеси залози та в яких діагностовано простатичну інтраепітеліальну неоплазію відносяться до підвищеної групи ризику виникнення РП. Гостра затримка сечі спостерігалася у 47\% з ДГПЗ, 50\% з РП та $83 \%$ у хворих з ПІН. За t критерієм Стюдента коефіцієнт достовірності між ДГПЗ та раком простати склав 0,3 що вказує на відсутність достовірної різниці. Коефіцієнт між ПІН та ДГПЗ і РП склав 2,06, що вказує на достовірну різницю.

Висновок. Отже хворі з ПІН частіше мають хронічний простатит, об'єм простати $60 \mathrm{~cm}^{3}$ і більше, цукровий діабет, у них частіше розвивається гостра затримка сечі та неефективні альфа 1 адреноблокатори. Різниці в клінічних даних між хворими на РП та ПІН, не виявлено. Враховуючі невелику вибірку, для отримання більш достоірних результатів слід проаналізувати більший масив даних. 


\title{
Література:
}

1. Чекалова А.О., Благодаров В.М., Романенко А.М., Піркко Харконен (2010) Хронічний атиповий проліферативний простатит, що розвивається під впливом довгострокової дії малих доз іонізуючого опромінення після аварії на ЧАЕС.

2. Литвиненко Р.А., Вітрук Ю.В., Стаховський О.Е., Прогностична значущість простатичної інтраепітеліальної неоплазії високого ступеня, № 4(12) 2013 р.

3. National Comprehensive Cancer Network (NCCN) Clinical Practice Guidelines in Oncology ${ }^{\mathrm{TM}}$. Prostate Cancer. National Comprehensive Cancer Network: Fort Washington, PA, Version 2.2014.

4. Bostwick D.G., Qian J. (2004) High-grade prostatic intraepithelial neoplasia. Mod. Pathol., 17: 360-379.

DOI https://doi.org/10.30525/978-9934-588-81-5-1.24

\section{КОРОНАВІРУСНА ХВОРОБА НА ЛЬВІВЩИНІ}

\author{
Іванченко Н. О. \\ асистент кафедри інфекційних хвороб \\ Львівський начіональний медичний університет \\ імені Данила Галицького \\ Федоренко С. М. \\ директор \\ Комунальне некомериійне підприємство Львівської обласної ради \\ «Львівська обласна інфекційна клінічна лікарня» \\ м. Львів, Украӥна
}

Коронавірусна хвороба 2019 року (COVID-19) - це гостре інфекційне захворювання дихальних шляхів, збудником якого $є$ новий коронавірус. Клінічна картина різноманітна: від легкого нездужання, подібного на застуду, до тяжкої вірусної пневмонії, що призводить до гострого респіраторного дистрес-синдрому. Характерні симптоми включають гарячку, кашель, задишку, міалгію, загальну слабість, аносмію. Велика частка хворих, які є джерелом інфікування оточуючих, $є$ безсимптомними [2, ст. 2]. Серед ускладнень, що зустрічаються найчастіше, домінують: поліорганна недостатність, i тромбози $[1$, ст. 2]. Лабораторна діагностика грунтується на виявленні РНК вipycy SARS-CoV-2 в мазках з рото та носоглотки. Метод імуноферментного аналізу є допоміжним в Україні і не $є$ підставою для включення випадку хвороби у статистику захворювань [3, ст. 6]. 88 